\title{
The Characteristics of Obesity in Children Aged Range 9-12 years on Elementary School in West Denpasar, Bali Indonesia
}

\author{
A A A L Paramasatiari ${ }^{1^{*}}$, and I N A Irwan ${ }^{1}$ \\ ${ }^{1}$ Faculty of Medicine, Warmadewa University, Jl. Terompong No 24, Denpasar 80235, Indonesia \\ *lilaparama84@gmail.com
}

\begin{abstract}
Obesity is a pathological state as due to exceed to consumption of food according the recommended daily food. The effect of the big consumption of food is the incident of obesity in children. The other factor of obesity are less physical activity, genetic factor, and fast food consumption. In Indonesia obtained that the problem of overweight and obesity in children aged 5 to 12 consecutive years of $10.8 \%$ and $8.8 \%$, is close to the estimated world figure in 2020 . The highest prevalence incidence of obesity in Bali Province is in Badung regency followed by Denpasar and the lowest is in Karangasem regency. The aim of this study was to find out the characteristics of obesity in children aged range 9-12 years in West Denpasar. The research method was cross sectional approach which was carried out among elementary school children in West Denpasar. The characteristics was observed concist of gender, physical activity pattern, and diet. The result were showed as follow the most common obesity in the study was found in male children (57\%). The highest percentage (53\%) of obesity was at 11 years old which among children who often eat fast food. Obesity was found most often (53\%) in children who often eat fast food, followed by children who rarely eat fast food (37\%), and at least (10\%) in children who never eat fast food. The obesity children who do light activity were $61 \%$, moderate activity were $23 \%$, and heavy activity were $16 \%$ respectively. It was concluded that the highest obesity percentage was due to light physical activity was often eat fast food.
\end{abstract}

Keyword : Obesity, Children, Elementary School.

\section{Introduction}

Obesity is a pathological condition in a person resulting from consuming food that exceeds their needs (psychobiological cues for eating) compared to the need for bodily functions, so that there is an accumulation of excessive fat that will interfere with health [1]. The adverse effects of obesity on health have a very close relationship with chronic diseases, such as high blood pressure, diabetes mellitus, and heart disease. Another impact that often occurs, especially in children, is a decrease in the level of intelligence due to decreased activity and creativity as well as conditions that make children tend to be lazy to move as a result of being overweight [2].

The incidence of obesity in children has several risk factors, including excessive food intake, consuming fast food, physical activity, environmental factors, and genetic factors [3]. Changes in socio-cultural, economic, and technological advances are also one of the risk factors for obesity incidence in children, especially in urban areas. 
The incidence of overweight and obesity in children globally increased from $4.2 \%$ in 1990 to $6.7 \%$ in 2010 . This is estimated to increase to $9.1 \%$, or equivalent to 60 million children in 2020 [4]. In Indonesia, overweight and obesity problems in children aged 5 to 12 years are shown respectively at $10.8 \%$ and $8.8 \%$, already close to the estimated world numbers in 2020 [5]. The prevalence is spread in 15 provinces, one of which is Bali. The highest prevalence of obesity in Bali occurs in the District of Badung, followed by Denpasar and the lowest in Karangasem [5].

Based upon the description of the dangers, risk factors, and obesity prevalence above, the depiction of the characteristics of obesity in children aged 9-12 years in the Province of Bali, especially in West Denpasar, can be drawn on

\section{Method}

\subsection{Location of the Study}

This research was conducted in West Denpasar, Bali, Indonesia in December 2017

\subsection{Design and Subject of the Study}

This study applied a descriptive observational research design, making use of a crosssectional approach. Data collection was conducted using a questionnaire to describe the characteristics of obesity in children aged 9-12 years at elementary schools in West Denpasar, Bali, Indonesia. The study involved one time data collection, which was then analyzed with a sample of 56 students in four elementary schools in Denpasar, yaitu SD Harapan Mulia Denpasar, SD Pelita Bangsa Denpasar, SD Negeri 19 Pemecutan, dan SD Negeri 27 Pemecutan, divided into categories with ranges age of 9-12 years.

\subsection{Variables and Methods of Data Collection}

The variables in this study are gender, age, physical activity patterns, eating patterns, and obesity. Data collection in this study was conducted by performing direct interviews which were assisted by questionnaire provided.

\subsection{Data Analysis Technique}

Data obtained from direct interviews using questionnaires were processed using a computer program. Then the data are presented in a single frequency distribution table. The analysis of all data is carried out in the program of Statistical Package for the Social Sciences for Windows (SPSS).

\section{Results And Discussion}

The data obtained were grouped into several criteria: respondent's sequence number, gender, age, diet, and physical activity.The results of data analysis obtained from sample data in the study are shown in table 1.

Table 1. Characteristics of Obesity in Children Aged 9-12 Years in Elementary Schools in West Denpasar

\begin{tabular}{lcc}
\hline & Characteristics & Frequency $(\%)$ \\
\hline Sex & & $32(57)$ \\
\hline Male &
\end{tabular}




\begin{tabular}{lc}
\hline \multicolumn{1}{c}{ Characteristics } & Frequency $(\%)$ \\
\hline Female & $24(43)$ \\
Age & \\
9 years & $9(16)$ \\
10 years & $12(21)$ \\
11 years & $20(36)$ \\
12 years & $15(27)$ \\
Eating Fast food & \\
Never & $5(10)$ \\
Rare & $21(37)$ \\
Physical Activity & \\
Mild & $34(61)$ \\
Modeate & $13(23)$ \\
Heavy & $9(16)$ \\
\hline
\end{tabular}

In table 1 , it can be seen that from 56 samples, the prevalence of obesity in men is $57 \%$ and in women is $43 \%$. The age group of obese children is at most 11 years old (36\%), followed by children aged 12 years $(27 \%)$, and the least $(16 \%)$ in children aged 9 years. The most prevalent obesity incidence $(53 \%)$ is found in children who often consume fast food, followed by children who rarely consume fast food (37\%), and the least (10\%) found in children who have never consumed fast food. From the analysis of 56 samples, the results showed that the incidence of obesity in children who did mild physical activity is $61 \%$, in children who did moderate physical activity is $23 \%$, and in children who did heavy physical activity is $16 \%$. relationship [6].

The results of this study indicate that obesity in men $(57 \%)$ is greater than women $(43 \%)$. This is in line with the national report on Basic Health Research (Riset Kesehatan Dasar or Riskesdas) which shows that the national prevalence of nutrition is more for people aged 6-14 years by genre, namely for men $9.5 \%$, and for women $6.4 \%$. [6] The similar fact was found through Suananda and Sidiartha's study which revealed that in the group of male children the incidence of obesity was more prevalent (46\%) compared to that of female children (25\%) [7]. In line with the results of Sartika's study which revealed that male children had a risk of obesity by 1.4 times compared to female children. This is possibly caused by girls more often restricting food consumption for the reasons of physical appearance [2].

In the present study, the highest prevalence of obesity occurred in children with an age group of 11 years (36\%), while the lowest was found in children with the age group of 9 years, which was $16 \%$. A similar fact was found by Khusnul, who in her study showed that the highest prevalence of obesity in primary school age children occurred in the group of children aged 11 years. This might be due to the number of children with an age group of 11 years is more than other age groups when the study was being conducted [8] In the current study it is found that the highest incidence of obesity $(53 \%)$ occurred in children who often consume fast food, followed by groups of children who rarely consume fast food $(37 \%)$, and the latter was the lowest incidence of obesity $(10 \%)$, occurring in children who have never consumed fast food.

The study of Badjeber et al., which was conducted to examine the consumption of fast food as a risk factor for the incidence of excessive nutrition in the students of SD Negeri 11 Manado, revealed that several factors leading obesity in children include excessive food intake and high calorie originating from instant foods, such as fast food, soft drinks, and eating foods containing glucose, such as candies. The results of the research using the odds ratio test show that there is a significant relationship that students who consume fast food more than 3 times 
per week can have a risk of 3.28 times greater than excessive nutrition compared to students who rarely consume fast food or the frequency is less than 3 times per week [9]. Rizkyi et al. in their study examined a significant relationship between the frequency of fast food and the incidence of over nutrition ( $\mathrm{p}<0.05)$, which implies that the frequency of consumption of fast food is one of the risk factors for the occurrence of over nutrition. There is a relationship between the frequency of fast food consumption and the incidence of over nutrition in elementary school students due to the wrong diet and also the influence of the surrounding environment, such as the easy access to buy fast food [10]. Putri stated that obese children have a intensive habit of consuming fast food, which generally has high energy because 40$50 \%$ contains fat [11].

The results of this study are also supported by the results of the Vertikal's study which states that there is a significant relationship between energy intake and over nutrition, in that, the respondents with high energy intake have a threefold chance of being over nutrition compared to respondents with sufficient energy intake [12]. Various theories have explained the mechanism of the relationship between energy and over nutrition. The excess energy derived from consuming excess food will be stored as body fat [13].

Physical activity is sports and other activities that involve body movements and are carried out as part of playing, working, driving actively, doing homework, and recreation [14]. The results of the present study indicate that the activity pattern with the highest percentage occurred in respondents who did mild physical activities (61\%), in children who did moderate physical activities (23\%), and the lowest number of obesity occurred in groups of children with heavy physical activities (16\%). In line with the results of a study conducted by Adirani and Wirjatmadi, the average PAQ-C score (physical activity) of respondents was 1.87, which means that on average respondents had mild physical activity. Lack of physical activity causes a lot of energy stored as fat so the tendency to be fat in people who have less physical activity occurs [15]. Zamzani's study revealed the same results, namely that the average duration of mild activity occurred in students with a higher prevalence of obesity compared to students with low obesity prevalence, while the average moderate and heavy activity was mostly donet by students who were not obese [16]. Simatupang's research entitled "Relationship between Physical Activity and Obesity Event in Elementary School Children in the City of Manado" obtained an OR: 3.59 (95\% CI: 1,565-8,238).This implies that children with mild physical activity have a risk of being 3 times more obese compared to children with moderate or severe activity. The results of the statistical test show the value of $p=0.004$, which means there is a significant relationship between physical activity and the incidence of obesity [16].

\section{Conclusions}

Based on the results and discussion elaborated in the previous chapter, the conclusion that can be drawn from this study is that the highest incidence of obesity in this study was found in male children $(57 \%)$. The highest obesity prevalence is found in children aged 11 year olds $(36 \%)$. The majority of obesity incidence occurs in groups of children who often consume fast food, with a percentage of $53 \%$. In addition, obesity is more common in the groups of children who only do mild physical activity, which is as much as $61 \%$. 


\section{References}

[1] Yoga P 2013 Prevalence and Characteristics Of Childhood Obesity In Pediatrics Outpatient Clinic, Sanglah Hospital Denpasar. Jurnal Ilmu Kesehatan Anak, 1.

[2] Sartika R A D 2011 Faktor risiko obesitas pada anak 5-15 tahun di Indonesia. Makara kesehatan, 15, 37-43.

[3] Kartini S 2013 Faktor Risiko Obesitas Pada Anak Usia 5-15 Tahun. Research Gate.

[4] Sjarif D R, Gultom L C, Hendarto A, Lestari E D, Sidiartha I G L \& Mexitalia M 2014 Diagnosis, Tata Laksana dan Pencegahan Obesitas pada Anak dan Remaja. Ikatan Dokter Indonesia.

[5] Pranata S, Fauziah Y, Asri Budisuari M \& Kusrini I 2013 Riset Kesehatan Dasar Dalam Angka. In: RI, K. K. (ed.). Badan Litbangkes.

[6] Rikerdas. Prevalensi Obesitas di Indonesia (Departemen Kesehatan Republik Indonesia) Available at : http://www.litbang.depkes.go.id (2010)

[7] Ali Suandana L N \& Sidiartha I 2014 Hubungan Aktivitas Fisik Dengan Obesitas Pada Anak Sekolah Dasar. E-Jurnal Medika Udayana, 3.

[8] Yaqin M K 2014 Prevalensi Obesitas Pada Anak Usia SD Menurut IMT/U. Jurnal Pendidikan Olahraga dan Kesehatan, Volume 02, pp. 114-118.

[9] Bedjeber Fauzul. Kapantouw H. Nova, Punuh Maureen 2012 Konsumsi Fast Food Sebagai Faktor Risiko Terjadinya Gizi Berlebih Pada Siswa SD Negeri 11 Manado: Fakultas Kesehatan Masyarakat Universitas Sam Ratulangi.

[10] Amalia R N, Sulastri D \& Semiarty R 2016 Hubungan Konsumsi Junk Food dengan Status Gizi Lebih. Jurnal Kesehatan Andalas, 5.(2016)

[11] Putri P A 2013 Perbedaan Asupan Energi, Lemak, Serat dan Aktivitas Fisik pada Anak Obesitas dan Non-Obesitas Usia 3-5 Tahun Available : http://eprints.undip.ac.id

[12] Vertikal L A 2010 Aktivitas Fisik, Asupan Energi, dan Asupan Lemak Hubungannya dengan Gizi Lebih pada Siswa SD Negeri Pondok Cina 1 Depok. Available from http://lib.ui.ac.id

[13] Almatsier S 2009 Prinsip Dasar Ilmu Gizi. Jakarta: PT. Gramedia Pustaka Utama. World Health Organization. Obecity and Overweight, (World Health Organization), Available at http://www.who.int/dietphysicalact ivity/childhood/en/ .

[14] Adriani M dan Wirjatmadi B 2012 Pengantar Gizi Masyarakat. Jakarta: Kencana.

[15] Zamzani M, Hamam H \& Astiti D 2016 Aktifitas fisik berhubungan dengan kejadian obesitas. Jurnal Gizi dan Dietik Indonesia, Vol 3.

[16] Simatupang 2018. Pengaruh pola konsumsi, aktivitas fisik, dan keturunan terhadap kejadian obesitas pada siswa sekolah dasar swasta di Kecamatan Medan Baru Kota Medan. Universitas Sumatera Utara Medan. 